\title{
Türkiye'de Ordu-Siyaset İlişkileri ve Askeri Darbelerin İdeolojik Kökenleri
}

\author{
MEHMET ZEKI DUMAN \\ zekiduman@yahoo.com \\ ORCID ID: 0000-0002-9369-9337
}

Öz: Türkiye'de ordu-siyaset ilişkileri ve bu ilişkilerin tarihsel, toplumsal ve ideolojik kökenlerine bakıldığında, iç ve dış politikadaki belirleyiciliği yanında, kendisini devletle özdeşleştirmiş, siyaseten toplumun üzerinde konumlandırmış, ideolojik açıdan modernleşmenin, batılılaşmanin ve Kemalizm’in öncülüğ̈̈̈nü üstlenmiş olan bir ordu profiliyle karşılaşmaktayız. Türkiye'nin bir ordu-millet devleti olmast ve kurucu unsurlarmın genellikle askerlerden oluşması, bir yandan sivil iradenin emrinde olması gereken ordunun hegemonik bir güç haline gelerek siyaset üstü bir konuma gelmesine, diğer yandan demokratik, çoğulcu ve sivil bir yönetim anlayışının oluşmasına engel olmuştur. Ordunun anayasal düzeyde kendisini konumlandırma ve tanımlama biçimi, Türkiyede darbelerin sıkça yaşanmasının ve sivillerin iktidar olsalar bile muktedir olamamalarmın en önemli nedenidir. Bu nedenlerin ideolojik kökenlerine inmeyi amaçlayan bu çalışma, "Türkiye'de neden askeri darbeler olur?” sorusuna cevap vermeye çalışmaktadır.

Anahtar kelimeler: Askeri darbeler, Ordu-siyaset ilişkisi, Devlet-millet kültürü, Demokratikleşme, Hukuk devleti.

\section{Giriş}

Askeri sosyolojinin en önemli konularından biri olarak karşımıza çıkan ordu-siyaset ilişkisi ve bu ilişkinin tarihsel, toplumsal ve siyasal boyutları hakkında bugüne kadar çok fazla araştırma yapılamamasının en temel nedeni, devletin kurucu unsuru olması yanında, katı kurallara ve hiyerarşik bir yapıya sahip olan ordunun kendi içinde kapalı bir özellik göstermiş olmasıdır. Zira ordu mensupları, kendilerini bir yandan rejimin teminatı, diğer yandan devrimlerin kollayıcısı olarak gördükleri için ülke yönetiminde de söz sahibi olmaları gerektiğine inanmışlardır. Bu inançtan hareketle meşru şiddet tekelini elinde bulunduran silahlı kuvvetler, yasalar çerçevesinde kendilerine tevdi edilen görev ve sorumlulukları yerine getirmekle sınırlı kalmamış,

\footnotetext{
* Doç. Dr., Van Yüzüncü Yıl Üniversitesi, Edebiyat Fakültesi, Sosyoloji Bölümü.
}

Bu makale, 26-28 Mayıs 2017 tarihleri arasında, Adnan Menderes Üniversitesi tarafından düzenlenen "27 Mayıs 1960'dan 15 Temmuz 2016’ya Darbeler, Geçmişten Günümüze Darbe Olgusu ve Millet Egemenliği Kültürü” Sempozyumunda sözlü bildiri olarak sunulmuştur. 
kimi zaman durumdan vazife çıkarmak suretiyle sivil otorite üzerinde tahakküm kurmaya çalışmıştır.

Tarih boyunca askerin devletle ve siyasetle olan ilişkisi hep tartışılagelmiştir. Bu ilişkiye atfen bir kurum olarak ordunun devlet düzeni içinde nasıl bir rol alması, hangi yetki ve sorumluluklara sahip olması ama daha da önemlisi yönetim mekanizması içinde kimi zaman ülkenin yüce çıkarları uğruna siyasete müdahalesinin nasıl engellenmesi gerektiği sorusu/sorunu her zaman güncel bir tartışma konusu olarak gündeme gelmiştir. Zira demokratik seçimlerle iktidara gelen siviller, seçilmiş olmaktan kaynaklı yönetme erkini kullanırken, bazen sınıfsal bazen de ideolojik nedenlerden olsa gerektir, bu erki devre dışı bırakacak askeri müdahalelere karşı her zaman teyakkuz halinde bulunmak zorunda kalmıştır. Ancak bu teyakkuz hâli, çoğu kez, ülkenin bağımsızlı̆̆ını ve ulusun bütünlüğünü gerekçe göstererek ihtilal yapan askerlerde çok fazla işe yaramamıştır.

Ordular, kurumsal ayrıcalıkları yanında devletten aldıkları güçle de her zaman siyasal yaşamın güçlü bir öznesi olmayı bilmişlerdir. Örgütlü bir yapı olarak toplumun kültürel tahayyülündeki militer değerlerinden beslenmiş ve bu sayede hegemonik konumunu sürdürmeyi başarmıştır. Buna karşın sivil otorite, her ne kadar ordunun yetkilerini hukuk içinde sınırlandırmaya çalışmış olsa da, ordu, genellikle devletle ilgili konularda söz söyleme hakkını kendisinde görmüş, bazen doğrudan bazen de dolaylı olarak siyasete müdahale etmekten çekinmemiştir. Dünyada birçok örneği olduğu gibi ordular, düzenin kurucu unsuru olduklarına inandıkları için sadece ülkelerinin savunma ve güvenliğinden sorumlu olmamışlardır, aynı zamanda yönetim ve siyasetle ilgili konuları da kendilerine vazife bilmişlerdir.

Modern ordular, gerek hiyerarşik yapıları ve kapalı grup özelliğini taşımaları, gerekse itaat ve disiplin içinde yetişmeleri ve ideolojik eğitimden geçmeleri gibi yapısal özelliklerinin yanında toplumda en güçlü örgütlü yapı olmaları nedeniyle de sivil otoriteler karşısında her zaman potansiyel bir tehdit oluşturmuşlardır. ${ }^{1}$ Nitekim Duverger $^{2}$ orduların devletlerin kurucu unsuru olarak öne çıktıklarını ve kimi zaman iktidar mücadelesine girmekten çekinmediklerini belirtir. Ona göre profesyonel ordular, aldıkları eğitim ve disiplin nedeniyle sürekli bir hükümet darbesi potansiyelini taşımaktadırlar. Oysa "tüm amaçları ve varlık nedenlerinin sadece devlete mutlak bağl1lık/devleti de kendine mutlak bağlamak ve devletin her türlü tehdide karşı korunması olan ordu, silahsız toplumun silahlı efendilerine boyun eğmelerini ve efendinin halk içinde güvenle iktidarını devam ettirmesini sağlamak için vardır."3

Silahlı gücü elinde bulundurmak, orduyu diğer kurumlardan farklı ve ayrıcalıklı kıldığı gibi, hegemonik üstünlüğü çoğu kez ona toplumsal ve siyasal olaylarda inisiyatif kullanma fırsatını da vermiştir. Dolayısıyla ordular, kendilerini toplumdan soyutlamadıkları gibi üyelerinin yaşamları da sadece kışlada geçmemektedir. Nitekim tarih bize çoğu kez devleti kuran bir güç olarak ordunun, rejimin koruyucu sıfatıyla

1 Doğan Akyaz, Askeri Müdahalelerin Orduya Etkisi, İstanbul: İletişim Yayınları, 2009, s.421-422.

2 Maurice Duverger, Diktatörlük Üstüne, çev., Bülent Tanör, İstanbul: Dönem Yayınları, 1965.

3 Maurice Duverger, Politikaya Giriş, çev., Samih Tiryakioğlu, İstanbul: Varlık Yayınları, 1964, s.123-126. 
hareket ettiğini, hegemonik meşruiyetini toplumun inanç ve değerlerinden ziyade kendi sınıfsal yapısından, ideolojik duruşundan veya ilkelerinden aldığını ve bundan dolayı sivil otoriteyle arasında kimi zaman gizli, kimi zaman açıktan bir çatışma yaşandığını göstermiştir.

Roma praetorian muhafızlarının tarihi, bu çatışmanın tarihteki ilk örneğini/arketipini oluşturmaktadır. Bilindiği gibi başlangıçta iç muhaliflere karşı kendisini ve yönetimini koruması için imparator Augustos tarafından kurulan seçkin muhafız ordusu, çok geçmeden istediği gibi imparatoru tahtan indiren ya da tahta çıkaran, desteğini en fazla para verene satan bir güç olmaya başlamıştır. ${ }^{4}$ Aynı zamanda imparatoru devirdiği için ordunun tarihteki ilk darbesi olarak da kabul edilen bu olay, zaman içinde asker ve sivil otorite arasındaki güvensizliğin temelini atmış ve o günden bugüne darbeler, toplumsal bir olgu olarak siyasal yaşamımızın önemli bir parçası haline gelmiştir.

Askeri darbeler neden olur? Özellikle de gelişmekte olan ülkelerde veya üçüncü dünya ülkelerinde darbelere neden sıkça rastlanır? Bu sorulara farklı cevaplar vermek mümkündür elbette, ancak esas soru(n), darbeleri gerçekleştiren ordunun hegemonik konumunun kökenlerinin neler olduğunu ortaya çıkarmaktır. Zira ordunun siyasi değişime karşı silahla karşı koymasının ve toplumun rızası olmadan sivil yönetimi devirmesinin nedenlerini ortaya koyacak güçlü analizlere ihtiyacımız bulunmaktadır. Siyaset bilimciler ${ }^{5}$ askeri darbelerin bazı özel koşulların neticesinde meydana geldiği konusunda hemfikirdirler. Bu özel koşullar; ekonomik gerilik, sivil yönetimlerin meşruiyetini kaybetmesi, ordu ve hükümet arasındaki ihtilaf ve darbe lehindeki uluslararası konjonktürdür.

Nitekim dünyada gerçekleşen her on darbeden dokuzunun azgelişmiş ülkelerde meydana gelmesi tesadüf değildir. Örneğin 1960'tan bu yana büyük çoğunluğu üçüncü dünyada olan 56 ülkenin askeri hükümet tecrübesi yaşadığına tanıklık ettik. Aynı şekilde toplumda yaygın yoksulluğun ve sosyal eşitsizliğin derinleşmesi, bir yandan hükümetin halk nezdindeki güvenini kaybetmesine, diğer yandan ordunun ekonomik gelişmeyi sağlama vaadiyle adım atmasına bir gerekçe oluşturmuştur. Ordu, muhtemelen sivil otoritenin toplumsal meşruiyetini kaybettiğini gördüğü zaman darbeye yeltenmektedir. ${ }^{6}$ Dolayısıyla darbeler, ekonomik gelişmişlik açısından üst düzeydeki ülkelerden ziyade alt düzeydeki ülkelerde yaygındır. ${ }^{7}$

Nasıl ki askeri darbelerin sıklığı ile az gelişmişlik arasında doğrudan bir ilişki söz konusuysa aynı şekilde darbelerin demokrasi kültürü ve siyasal kurumsallaşma düzeyiyle de ilişkisinin olduğu söylenebilir. Diğer bir deyişle demokratik kültürün toplumsal tabanda kurumsallaşmadığı ya da yeterli ağırlığa sahip olmadığı yönetimler-

4 William Hale, Türkiye'de Ordu ve Siyaset, çev., Ahmet Fethi, İstanbul: Hil Yayınları, 1996, s.255.

5 Bu konuda şu kaynaklara bakılabilir: Samuel P. Huntington, "Political Development and Political Decay” World Politics, 17/3 (1965): 386-430; Henry Kissinger, World Order, New York: Penguin Books, 2014; Francis Fukuyama, Political Order and Political Decay, New York: Farrar, Straus and Giroux, 2014.

6 Andrew Heywood, Politics, New York: Palgrave Macmillan, 2007, s.411.

7 Samuel P. Huntington ve Jorge I. Dominguez, Siyasal Gelişme, çev., Ergun Özbudun, Ankara: Ankara Siyasal İlimler Derneği Yayınları, 1975, s.13. 
de ordu değişimin önünü kesebildiği gibi bazen de değişimin itici gücü olabiliyor. $\mathrm{Bu}$ anlamda demokrasi ile darbe bir terazinin iki kefesi gibidir, birisi alçalmadan diğeri yükselmez. ${ }^{8}$ Örneğin dünya düzeyinde bakıldığında darbelerin adeta gelenek halini aldığı toplumlarda siyasal kurumsallaşma düzeyinin oldukça düşük kaldığını, demokratik teamüllerin yeterince yerleşmediğini ve siyasetin de özerkleşmediği görüyoruz. ${ }^{9}$

Askeri darbelerin demokrasi ve ekonomik gelişmişlikle ilişkisini anlayabilmek için, bugüne kadar dünyada meydana gelmiş olan darbelerin hangi kitalarda/ülkelerde gerçekleştiğine bakmamız yeterlidir. Örneğin 1950'den bugüne darbelerin coğrafi ve oransal dağılımına bakıldığında ilk sırayı Afrika kıtasının (101) \%42.8) aldığını, Afrika'yı, Latin Amerika (70) \%29.7), Orta Asya/Asya (36) \%15.3), Ortadoğu/Arap Yarımadası (21) \%8.9) ve Avrupa (8) \%3.4) takip ettiğini görüyoruz. ${ }^{10}$ I. Dünya Savaşından bugüne toplamda 475 askeri darbe girişimi yaşanmış ve bu darbe girişimlerinin 236'sı amacına ulaşırken, 239'u başarısız olmuştur. Son 50 yıl içinde Avrupa'da herhangi bir darbe girişimi yaşanmazken, darbe girişimlerinin büyük bir çoğunluğu Afrika'da ve Latin Amerika'da gerçekleşmiştir. ${ }^{11}$

Türkiye’nin durumuna bakıldığında çok partili seçim sistemine geçtiğimiz 19462dan bugüne Ordu'nun, 1960, 1971, 1980 ve 1997 yıllarında olmak üzere toplamda dört kez yönetime müdahale ettiğini, gündelik yaşamda çoğu kez "siyasal yargıçlığa" soyunduğunu, siyasal oyunda sinırları belirleyen ve bunlara uyulmasını sağlayan bir tür vasi gibi hareket ettiğini görüyoruz. Aynı şekilde birleştirici, hatta yeniden yapılandırıcı bir güç olarak ortaya çıkan Ordu’nun, sonuçta "ulusun ta kendisi", "anavatanın ve vatanseverlik inancının bekçisi”, ulus devletin birliğinin, bağımsızlığının ve istikrarının güvencesi olarak kendisini takdim ettiğini görüyoruz. ${ }^{12}$ Coğrafi ve oransal dağılımına baktığımızda şöyle bir tabloyla karşılaşıyoruz.

Dolayısıyla hegemonik bir güç olarak Ordu'nun Türkiye'de sadece kurucu bir unsur, rejimin teminatı veya resmi ideolojinin bekçiliğini yapan bir sıfatla öne çıkmadığını, aynı zamanda devletin gerçek sahibi olduğuna ve ülkeyi koruma ve kollama misyonunu taşıdığına inanarak hareket ettiğini söylememiz mümkündür. Bu açıdan "ordu neden darbe yapıyor" sorusunun altında yatan toplumsal ve ekonomik nedenler yanında, özellikle ideolojik nedenler bilinmeden, söz konusu askeri darbeleri anlamamız da pek mümkün görünmüyor. Bu soruya yerinde cevap verebilmek için de ordunun yasalardan bağımsız olarak kendi kendisini nasıl tanımladığına ve bu tanımdan hareketle kurumsal kimliğine ve tarihsel rolüne dayanarak kendisini sivil irade karşısından nasıl gördüğüne bakmamız gerekiyor.

8 Özcan Yeniçeri, Genç Osman'dan Menderese Darbe ve Demokrasi, Ankara: Kripto Yayınları, 2015, s.372.

9 Huntington, "Political Development and Political Decay", s.386.

10 Bengi Cengiz, “İkinci Dünya Savaşı’ndan Sonra Dünyadaki Darbeler ve Darbe Girişimleri”, son güncelleme 07 Ağustos, 2018. http://www.dogrulukpayi.com/bulten/ikinci-dunya-savasi-ndan-sonra-dunyadaki-darbeler-vedarbe-girisimleri.

11 “Dünyada 1950'den Beri 475 Askeri Darbe Girişimi Oldu”, Haberler.com, son güncelleme 15 Ağustos, 2018. https://www.haberler.com/dunyada-1950-den-beri-475-askeri-darbe-girisimi-10427351-haberi /.

12 Levent Ünsaldı, Türkiye'de Asker ve Siyaset, İstanbul: Kitap Yayınları, 2008, s.13. 


\section{Osmanlı Döneminde Ordu-Siyaset İlişkisi}

Cumhuriyet döneminde yaşanan askeri darbelerin kökeni Osmanlı İmparatorluğuna kadar dayandırılabilir. Örneğin Osmanlı padişahlarının yaklaşık üçte biri askeri müdahaleler sonucu tahtan indirilmiştir. ${ }^{13}$ Özellikle III. Selimden itibaren askerler, yönetim üzerinde hegemonik bir güç olmaya başladıkları için genellikle sınıfsal çıkarları nedeniyle padişahın reformist politikalarına karşı çıkmışlar veya isyan ederek yönetime el koymuşlardır. ${ }^{14}$ Cumhuriyet rejiminin kurucuları da geç Osmanlı döneminin askeri kadrolarından teşekkül etmiştir. Bu dönemde neredeyse kurucu kadronun tümünün asker kökenli olması, hem bir kurum olarak ordunun, hem de silahlı gücü elinde bulunduran askerin ülke yönetiminde öncelikli bir yer edinmesini sağlamıştır.

Osmanlı'da askerin siyasetle ilişkilerini anlamak için öncelikle imparatorluğun toplumsal ve siyasal yapısını bilmek gerekir. Osmanlı, yöneten ve yönetilen arasında keskin bir ayrımın yaşandığı, toplumda ekonomik sermayeden çok askeri statüye yönelik değerlerin ağır bastığı, Avrupa'nın aksine devlet ve toplum arasında kilise, loncalar veya özerk şehir yönetimleri gibi ara ya da tampon yapıların bulunmadığı, genellikle mülkiyetin tümüyle devlete ait olduğu ve dolayısıyla yerli bir aristokrasinin olmamasından dolayı bütün yetkileri elinde bulunduran bir yönetiminin söz konusu olduğu bir imparatorluktur. Bu imparatorluk yapısı, doğal olarak mutlak gücü elinde bulunduran devlete karşı zayıf bir sivil toplumun oluşmasına yol açmıştır ki, böylece zaman içinde sivil iradenin muktedir olmasını sağlayacak demokratik bir kültürün oluşması da engellenmiştir. ${ }^{15}$

Böylece Osmanlı patrimonyal yönetim sistemi içinde devletle özdeşleşen ordu, toplumda olduğu kadar siyasette de ayrıcalıklı ve öncelikli bir yer edinmiştir. Ordunun bu öncelikli yerini anlamak için Osmanlının sınıfsal yapısına daha yakından bakmak gerekir. İmparatorluğun toplum yapısına baktığımızda ise üç farklı yönetici zümresiyle karşılaşmaktayız. Bunlardan birincisi, daha çok kırsalda yaşayıp, tarımla uğraşan ve elde edilen gelirin bir kısmını devlete veren Timarlı Sipahiler, ikincisi, kent merkezinde özellikle başkentte yaşayıp profesyonel memurlardan oluşan $\mathrm{Ka}$ pıkulları, üçüncüsü de din, eğitim ve adalet gibi işlerle uğraşan Ulemadır. Devletin, eyalet ve donanma kuvvetlerini oluşturan, doğrudan padişaha bağlı olup profesyonel orduyu oluşturan kapıkulları ise, Osmanlı ordusunun adeta belkemiğini oluşturmuştur.

Osmanlı toplumunun ayırıcı bir özelliği olarak öne çıkan bu sınıfsal yapı, aynı zamanda imparatorluğun çok kültürlü yapısını yıllarca belli bir dengede tutma-

13 Osmanlı döneminde toplamda 12 padişah isyan veya darbe sonucu tahttan indirilmiş (beş tanesi öldürülmüş, bir tanesi zehirlenmiş) altmışa yakın sadrazam da darbeyle öldürülmüştür (Erol Maraşli, Türkiye’de Askeri Darbe Teşebbüsleri, İstanbul: Bilgeoğuz Yayınları, 2015, s.113).

14 Yeniçeriler, ulemayla ittifak içinde konumlarını tehdit edebilecek her tür toplumsal veya siyasal, askeri reforma karşı muhalefet etmişlerdir (Feroz Ahmad, Bir Kimlik Peşinde Türkiye, çev., Sedat C. Karadeli, İstanbul: İstanbul Bilgi Üniversitesi Yayınları, 2006, s.32).

15 Ergun Özbudun, Otoriter Rejimler, Seçimsel Demokrasiler ve Türkiye, İstanbul: İstanbul Bilgi Üniversitesi Yayınlar1, 2011, s.128-129. 
yı başarmıştır. Ta ki, Batı karşısında askeri yenilgilerin oluşturduğu büyük toprak kayıplarının siyasal iktidarı reformlara zorlamasına kadar. Reformlar karşısında ulemayla ittifak yapan askerler, Nizam-ı Cedit döneminden itibaren kimi zaman açıktan kimi zaman da gizliden devleti yönetmiştir. ${ }^{16}$ Osmanlıda toplumsal ve siyasal örgütlenmenin inşa olunmasında esas dayanağın devletle özdeşleşmiş bir ordunun oluşturması, ${ }^{17}$ askerin batıda olduğu gibi sadece güvenlik işleriyle değil, saray ve bürokrasiyle de ilgilenmesini ve devlet zaafa düştüğünde padişahla pazarlığa girişerek iktidarın belirlenmesinde aktif rol almasını da sağlamıştır. ${ }^{18}$

$\mathrm{Bu}$ açıdan bakıldığında Osmanlıda silahlı kuvvetlerin siyasal sürecin ana öznesi olmasının, hatta padişahları tahttan indirip tahta çıkarılmasında egemen bir rol oynamasının, Türk yönetim ve idare geleneğinin adeta temel özelliğini oluşturduğunu söyleyebiliriz. ${ }^{19}$ Yönetim ve idare yapısı içinde ordunun devletle özdeşleşmesi ve toplumda askerlik mesleğinin yüceltilmesi, Osmanlı toplumunun karakteristik bir özelliği olarak okunabilir. Hatta kimi yazarlar, ${ }^{20}$ Osmanlı'da askerin siyasal iktidar üzerinde baskı kurmasının ve Batıda gelişen endüstriyel kapitalizme ayak uyduramamasının dolayısıyla ekonomik açıdan gelişememesinin temel nedeninin, devletin ticarete önem vermemesine ve askerlik mesleğini adeta kutsallaştırmış olmasına bağlamışlardır. Hatta 18. yüzyıldan kalma bir belgeden hareketle Steinhaus ${ }^{21}$ şu çarpicı tespitlerde bulunuyor:

Osmanlı İmparatorluğunda genel olarak ticaret hiç bir zaman Müslümanların uğraşı olmamıştır. Onlar ticareti Rumlara, Ermenilere ve özellikle imparatorluğa en iyi alışveriş olanaklarını sağlayan Musevilere bırakmışlardır... Dolayısıyla endüstri ve burjuva devrimlerini hazırlayan önkoşulların Osmanlı İmparatorluğunda hiçbir zaman oluşmaması dış etkenlere bağlanamaz. Bu gelişmenin asıl nedenlerini Türk Devleti'nin sosyal tarihsel oluşumunda ve toplum yapısında aramak gerekir. Osmanlı toplumu her ne kadar farklı kimlik ve kültürlerden oluşsa da merkezi yönetim ve idare Türklerden oluşmuş ve Türkler, yukarıda da belirtildiği gibi ekonomi ve ticaretle uğraşmak yerine askerlik mesleğiyle ilgilenmişlerdir.

Türk modernleşmesi üzerine yazdığı eserlerle tanınan Feroz Ahmad de, ${ }^{22}$ Osmanlının kendi dönemi içinde çok fazla şey ifade etmeyen ticaret yerine imparatorluğu ayakta tutan askerlik mesleğine önem verdiğini ve askeri yenilgilerin başlaması üzerinde de gerilemeye başladığını iddia etmiştir. Ona göre Osmanlılar, her ne kadar ekonomi açısından ticaretin önemini kavrasalar da aslında hiç bir zaman sadece ticaret sınıflarının çıkarlarıyla ilgili olmadıkları gibi, ekonominin hızlı büyümesine dair bilinçli bir ilgi de göstermediler. İmparatorluğun yönetici sınıfının karakteristik

16 Fikret Başkaya, Yediyüz, Ankara: Ütopya Yayınları, 1999, s.18.

17 Erhan Afyoncu, Ahmet Önal ve Uğur Demir, Osmanlı İmparatorluğu'nda Askeri İsyanlar ve Darbeler, İstanbul: Yeditepe Yayınevi, 2016, s.11.

18 Şükrü Karatepe, Darbeler, Anayasalar ve Modernleşme, İstanbul: İz Yayıncılık, 1999, s.23.

19 Metin Öztürk, Ordu ve Politika, Ankara: Gündoğan Yayınları, 1993, s.174.

20 Hale, Türkiye'de Ordu ve Siyaset, s.14-19.

21 Kurt Steinhaus, Atatürk Devrimi Sosyolojisi, çev., Mehmet Akkaş, İstanbul: Sarmal Yayınları, 1995, s.22-23.

22 Ahmad, Bir Kimlik Peşinde Türkiye2006, s.21-23. 
özelliği, tutucu ve statükoya bağlı olmalarıydı, bu yüzden de bir tüccar sınıfının ortaya çıkarak devleti dönüştürüp eski yönetici seçkin tabakayı yerinden etmesine izin vermezlerdi.

Bu tespitler bize tıpkı diğer imparatorluklarda olduğu gibi ama daha fazla bir biçimde Osmanlı'da askerliğin ne anlama geldiğini ve fetih mantığına dayanan imparatorluğun ne derece orduya dayandığını göstermektedir. Osmanlıda ordunun devletin belkemiğini oluşturması, askerlik dışı işlerle uğraşan köylülerin ve diğer üreticilerin devlete ve askerlik işinde kendisiyle işbirliği yapan sınıflara bağımlı olmasına da yol açmıştır. Bu durum, Osmanlı'da ikili bir sınıf yapısını doğurmuştur. Birincisi savaşan ve aynı zamanda bürokrasiyi de oluşturan yönetici konumundaki askeri sınıf, ikincisi de daha çok asker dişındaki reaya ve kent merkezindeki sınıflardır. ${ }^{23}$ Ancak, sosyal örgütlenme açısından en avantajlı sınıf, aynı zamanda doğrudan padişaha bağlı olmasına karşın özellikle gerileme dönemiyle beraber kendi sınıfsal çıkarlarını her şeyin üstünde gören seyfiye sınıfı olmuştur.

Kanuni dönemine kadar İmparatorluğun sınıfsal, yönetsel ve bürokratik yapısında ciddi bir sorun yaşanmamıştır. Ancak, 18. yüzyılın sonlarına doğru gelindiğinde toprak kayıplarının artması üzerine bazı idari ve askeri kurumlarda reform yapılması düşüncesi gündeme gelmiş, ancak sınıfsal çıkarlarına aykırı olması nedeniyle ulema ile ittifak kuran seyfiye (asker) kesimi, bu reformlara şiddetle karşı çıkmıştır. ${ }^{24}$ Nitekim Osmanlı'da darbe geleneğini başlatan olaylar zincirinin imparatorluğun gerilemeye başladığı, eşitsizliğin, yoksulluğun rüşvet, adam kayırma ve israfın arttığı bir dönemde başlaması tesadüf değildir. Yaşanan sorunların siyasal iktidarı reformlara zorlaması, yukarıda da vurgulandığı gibi orduyu bir hayli rahatsız etmiştir. Bu rahatsızlık, bir yandan padişahın yapısal reformlara gitmesini, diğer yandan ordunun modernleşmesini engellemiştir.

Osmanlının askeri düzenini ve idari yapısını değiştirmeyi hedefleyen girişimler, arkasına ulemanın da gizli desteğini alan ve mali açıdan da devlete yük olmaya başlayan yeniçerileri farklı arayışlara sevk etmiştir. Burada ordu, silah zoruyla iktidar üzerinde baskı kurarken, ulema da kurulu düzenin ideolojik aygıtı olarak işlev görmüştür. Padişahın, hareket kabiliyetini ve teknolojik üstünlügüüü kaybettiği için savaşlarda sürekli yenilgi almaya başlayan ve yönetimin emirlerini dinlemeyen askeri sistemi değiştirmeye kalkışması, mevcut düzende ısrar eden ve ordunun belkemiğini oluşturan yeniçerilerin önce isyan etmesine, ardından padişahı devirmeyi amaçlayan darbe girişiminde bulunmasına yol açmıştır. Darbe yapmak suretiyle iktidarı baskı altına almayı amaçlayan subaylar, orduyu da siyasallaştırmış ve siyasallaşan ordu, ilk darbe girişimini 1859'da Kuleli Vakası olarak bilinen olayda yapmış, sonra II. Meşrutiyet 1908'de, 31 Mart Olayıyla 1912'de Halaskar Zabitan Hareketi'nde ve 1913’te Bab-1 Ali Baskını'yla siyasete müdahale etmeye devam etmiştir. ${ }^{25}$

23 Muzaffer Sencer, Osmanlı Toplum Yapısı, İstanbul: Sarmal Yayınları, 1999, s.215.

24 Erik Jan Zürcher, Modernleşen Türkiye’nin Tarihi, çev., Yasemin S. Gönen, İstanbul: İletişim Yayınları, $2004 ;$ H. Kemal Karpat, Osmanlıdan Günümüze Asker ve Siyaset, İstanbul: Timaş Yayınları, 2010, s.63-68.

25 Konu hakkında şu kaynaklara bakılabilir: Sina Akşit, 31 Mart Olayı, Ankara: İmge Kitabevi, 2015; Şerif Mardin, Jön Türklerin Siyasi Fikirleri 1895-1908, İstanbul: İletişim Yayınları, 2017; Metin Heper, Türkiye’de Devlet 
Başta Enver Paşa ve Talat Bey olmak üzere bir grup İttihat ve Terakki üyeleri tarafından 1908'de Bab-1 Ali Baskınıyla gerçekleştirilen darbe olayı ve sonraki yıllarda siyasi tarihimizde aktif rol alacağ 1 anlaşılan ordu, ${ }^{26}$ Türkiyede darbelerin adeta gelenek halini almasına ve askeri vesayetin kalıcı hale gelmesine neden olmuştur. Burada, bu geleneğin fiili başlatıcısı konumundaki İttihat ve Terakki Cemiyetinin özel rolü üzerinde durmakta yarar var. Zira cemiyet, Osmanlı’nın yıkılmaya başladığg ve herkesin çözüm arayışına girdiği bir dönemde tarihi bir görev üstlenmiştir. "Osmanlı Devleti nasıl kurtulur?” sorusunun sorulduğu bu dönemde, sonradan İttihat ve Terakki kadrosunu oluşturacak Jön Türkler, devletin inşa sürecinde fikirleriyle öne çıkmıştır.

Milliyetçiliğin yayılmasıyla Osmanlı'nın toprak kaybetmeye başlaması, Avrupadaki Türk aydınlarının ülke sorunlarını görüşmek üzere bir araya gelmesini sağlamıştır. Bir zamanlar üç kıtaya hükmeden Osmanlının yıkılmasına seyirci kalamayan aydın, asker ve bürokratlar, yeni bir kuşağın sesi olarak örgütlenmeye ${ }^{27}$ ve devletin özerkliğini ve coğrafi bütünlüğünü korumanın yollarını aramaya başlamışlardır. Aslında burada Jön Türklerin öncülüğünde yapılmak istenen şeyin, yani özünde devleti kurtarmak düşüncesinin, geleneksel düzeni ve bürokrasinin ayrıcalıklı konumunu değiştirmeden korumanın sembolik formülü haline gelmesine yol açtığı söylenebilir. ${ }^{28}$ Nitekim İttihat ve Terakki açısından devleti kurtarmak, var olan geleneksel düzenin yeni aktörler eliyle yeniden inşa etmek anlamıma gelmiştir.

Türk politik yaşamında İttihat ve Terakkinin başlattığı hareket, hem geç Osmanlı'nın hem de erken Cumhuriyet döneminin siyasal yapısı üzerinde ciddi etkiler bırakmıştır. Zira İttihatçılar, ülkenin gidişatından kaygı duydukları için dağılmakta olan Osmanlı'nın yerine Türk etnisitesine dayalı yeni bir ulus-devlet inşa etme arayışına girmiş $^{29}$ ve bu arayışın neticesinde Avrupa'daki aydınlar, çökmekte olan imparatorluğun geleceğini görüşmek üzere bir araya gelerek örgütlenmişlerdir. Örgütlenen aydınlar, yapmış oldukları görüşmeler ve tartışmalar neticesinde kendi içinde iki farklı gruba ayrılmışlardır. Birinci grup, Ahmet Rıza önderliğinde 1895’ten beri Avrupa'da Osmanlıca ve Fransızca dillerinde Meşveret adında bir gazete çıkaran, kendilerine Jön Türk adını veren ve sonradan İttihat ve Terakki adıyla örgütlenen kesimdir. ${ }^{30}$ Genellikle pozitivist bir dünya görüşüne sahip aydınların yer aldığı bu kesim, merkezi bir yönetimin ve Türk ulusçuluğuna dayalı milli bir devletin kurulması fikrini savunmuşlardır.

İttihatçıların başını çeken Ahmet Rıza, devletçiliğin, merkeziyetçiliğin, ilerleme ve gelişmenin yolunu, öncelikle devleti kurtarmaktan ve düzeni sağlamaktan geçtiğine inanmıştır. ${ }^{31}$ Dönemin milliyetçilik akımlarından ziyadesiyle etkilenen ve kurtuluşu Türk ulusçuluk bilincinin yaratılmasında gören Rıza, öncelikle yıkılmaya yüz tutmuş

Geleneği, çev., Nalan Soyarık, Ankara: Doğu Batı, 2006.

26 Hale, Türkiye'de Ordu ve Siyaset, s.43.

27 Niyazi Berkes, Türkiye’de Çağdaşlaşma, İstanbul: Yapı Kredi Yayınları, 2005, s.403.

28 Çağlar Keyder, Türkiye’de Devlet ve Sinıflar, İstanbul: İletişim Yayınları, 2001, s.78.

29 Şerif Mardin, Türkiye'de Toplum ve Siyaset, der., Mümtaz’er Türköne ve Tuncay Önder, İstanbul: İletişim Yayınlar1, 1997, s.221.

30 Zürcher, Modernleşen Türkiye’nin Tarihi, s.131.

31 Cengiz Aktar, Türkiye’nin Batılılaştırılması, çev., Temel Keşoğlu, İstanbul: Ayrıntı Yayınları, 1993, s.38. 
imparatorluğun toprak kayıplarının durdurulması için askeri reformlara hız verilmesini savunmuştur. 'Türklerin Türklerden başta dostu yoktur' şiarından beslenen bir düşünceyi hararetle savunurken, zamanın ruhuna ve çağın gereklerine uygun yeni bir Türk devletinin temellerinin atılmasını istemiştir. İttihatçılar, bu düşünceden hareketle önce düzeni sağlamak suretiyle millet egemenliğini tesis etmeyi sonradan da Türk ulus-devletini kurmayı öğütlemişlerdir. İttihatçıların savunduğu fikirler, sonradan başta Atatürk olmak üzere kurtuluş savaşını başlatan kurucu kadrolar ve bazı asker-sivil bürokratlar tarafından da benimsenmiştir.

Avrupa'daki aydınların bir kısmı Osmanlının kurtuluşu ve geleceği konusunda İttihatçılardan farklı bir yol takip etmişlerdir. İkinci grup içinde yer alan bu aydınların başını Prens Sabahattin çekmiştir. Sabahattin, Devlet-i Âli'yenin kurtuluşunu, temelde adem-i merkeziyetçilik denen sistemde yani yerinden yönetim denilen idari yapının güçlendirilmesinde görmüştür. Bunun yanında eğitim ve bürokratik kurumların reforme edilmesi, merkezi yönetimin adli, idari ve askeri bazı yetkilerini yerel otoriterlerle paylaşması, devletçilikten vazgeçilerek şahsi teşebbüsün güçlendirilmesi, üretim ve yatırımın desteklenmesi daha da önemlisi bireye itaat kültürünü aşılamak suretiyle onu devletin kapısına muhtaç bırakan eğitim sisteminin liberalleştirilmesi istenmiştir.

Avrupa'daki aydınların “Osmanlı nasıl kurtulur?” sorununa verdikleri cevap, birinci grubu oluşturan milliyetçilerle ikinci gruptaki liberalleri karşı karşıya getirmiş ve bu karşılaşmadan İttihatçılar galip gelerek, hem fikirleriyle hem de kadrolarıyla devletin kurucu felsefesini ve cumhuriyetin epistemolojisini inşa etmişlerdir. İttihatçlar, çökmekte olan imparatorluğu yeniden ayağa kaldırmanın mümkün olmadığını gördüklerinden olsa gerektir, yeni bir ulus-devlet yaratmanın çabasını vermişlerdir. İttihatçılar, düşündüklerini gerçekleştirmek için öncelikle devleti ele geçirmeyi, bunun için de siyasi iktidarı yönetimden uzaklaştırmayı hedeflemişlerdir. Bu hedefe ilk kez, 1908'de gerçekleştirdikleri darbeyle ulaşmışlardır. Yönetime el koymak suretiyle devletin ele geçirilmesi, devletin ordu, ordunun da devlet haline gelmesi sağlamış$\operatorname{tır}^{32}$ ve o günden bugüne darbeler Cumhuriyet dönemine de sirayet ederek siyasi hayatımızın adeta ayrılmaz bir parçası oluvermiştir.

\section{Cumhuriyet Döneminde Ordu-Siyaset İlişkisi}

1908'de yapılan darbeyle yönetimi ele geçiren İttihatçılar Cumhuriyet rejiminin temellerini atmış, Osmanlı ordusunun subayları olarak kurtuluş mücadelesini vermiş ve nihayetinde Türkiye devletini kurmuşlardır. Devleti kuran bir güç olarak ordu, bu dönemde de gerek ideolojisiyle, gerek felsefesiyle siyasetin ana aktörü olmayı sürdürmüş, sosyal, ekonomik ve toplumsal yaşamı düzenlemeye ve modernleşme harekelerine öncülük etmeye çalışmıştır. Zira bu dönemde Osmanlı'dan aşkın bir devlet ve zayıf bir sivil toplum mirası alındığı için ülkenin inşa edilmesinde sivil bürokrasi ile askerler arasındaki zımni ittifak da devam etmiştir. Siyasetin ve toplumun askeri bürokrasi tarafından dizayn edilmesi, aynı şekilde Osmanlının aşkın devlet geleneğinin sürdürülmesi, cumhuriyet rejiminin de ordu-devlet halini almasına neden olmuştur. 
Ordu, sivil toplum ve burjuvazi gibi sınıfsal ve örgütsel yapıların olmadığı bu dönemde koşullar gereği üstüne vazife olmayan memleket meselelerine de el atmaya mecbur hissetmiştir. Bu açıdan bakıldığında şimşekleri üzerine çekmiş ve sürekli eleştiri yağmuruna tutulmuş olan ordunun neden kışlasında oturmadığı sosyal, ekonomik, kültürel ve siyasal yaşama müdahale etmek zorunda kaldığg anlaşılıyor. Ancak anlaşılmayan bir şey varsa, o da, ordunun sivil alana müdahalesini bir alışkanlık haline getirmesi ve bunu kendisinde bir hak olarak görmesidir. Dünyamız artık yüzyılın başındaki bir dünya değildir, her kurum gibi askerler de değişen koşullara göre harekete etmek zorundadır. Maalesef ordu mensupları, devletin kurucu ve kollayıcısı olduklarına inandıkları için sivil otoritenin tasarruflarına da karışabilmektedir.

$\mathrm{Bu}$ açıdan bakıldığgnda Türkiye'de ordunun tarihsel mirasının üç ana öğesinden söz etmek mümkündür. Birincisi, yukarıda da vurgulandı, Osmanlı'dan itibaren ordunun neredeyse tümüyle devletle özdeşleşmesi, ikincisi ordunun modernleşmenin ve batılılaşmanın öncüsü olması, üçüncüsü de, Cumhuriyetin ilk yıllarından itibaren ordunun sadece devletin güvenliği ile ilgili değil, aynı zamanda günlük politikanın içeriğine de müdahale etme alışkanlığını sürdürmesidir. ${ }^{33}$ Devlet güvenliği gerekçe gösterilerek sivil yaşama yapılan her tür müdahale Türkiye'de demokrasinin, insan hakları ve hukukun gerilemesine neden olmuştur. Nitekim neredeyse her on yılda bir yapılan askeri müdahaleler, Türkiye'nin muasır medeniyet seviyesine çıkma hedefini, çağdaşlaşma ve modernleşme çabasını sekteye uğratmış, sivil siyasetin ve demokratik kurumların güçlenmesini engellemiştir.

Ordunun tarihten getirdiği ve güçlü bir biçimde bağlı olduğu 'devletin sahibi olma' kültü, zaman içinde adeta bir gelenek halini almış ve bu gelenek ordunun kışlasında durmayıp sivil otoriteler karşısında sürekli teyakkuzda bulunmasına neden olmuştur. Bu psikolojik hâl nedeniyle devletin veya rejimin güvenliğiyle ilgili en ufak bir durum sezildiğinde devletle kendisini özdeşleştiren ordunun müdahaleci yanı ortaya çıkarmıştır. Bu durum aynı zamanda Osmanlı'daki 'devlet nasıl kurtulur' sorusunun Cumhuriyet rejiminde 'devlet nasıl korunur' sorusuna dönüşmesine neden olmuştur. ${ }^{34}$ Oysa milli mücadele sonrasında askerin konumu, devlet içindeki rolü ve siyasetle olan ilişkisi hakkında tartışmalar gündeme geldiğinde Atatürk başta olmak üzere devletin kurucu kadroları, ordunun tümüyle siyaset dışında kalması gerektiğinde ittifak etmişlerdir.

Erken cumhuriyet döneminde ordunun siyaset dişı kalması gerektiği fikri, Türkiye’nin demokratikleşmesi açısından elzem görülmüşsür. 'Ne partinin silaha, ne de silahın partiye kumanda etmemesi gerekir' görüşü, Cumhuriyet kadroları tarafından ilkesel olarak kabul görmüştür. 'Ordu, siyasete bulaşmamalı' yaklaşımının ortaya çıkmasında daha öncesinde yaşanan II. Meşrutiyet deneyiminin ve Birinci Mecliste ordu üzerinden yürütülen muhalefetin de etkisi olmuştur. Yöneticiler, siyasal iktidarın kaynağ1 olarak orduyu değil, parlamentoyu göstermiş, ulusal egemenliği ve milli iradeyi temsil edecek yegâne kurum olarak da meclisi işaret etmiştir. Ancak, ulusal

33 Hale, Türkiye'de Ordu ve Siyaset, s.14.

34 Çetin, Modernleşme ve Türkiye’de Modernleștirme Krizleri, s.232. 
çıkarlarla ve devletle özdeşleşmiş bir ordu yapısının kendi içinde özerkleşmesi yanında siyasetten de uzaklaşması mümkün olmadığından ${ }^{35}$ ordunun kışlasında durması ve siyasete bulaşmaması gerektiği fikri bir türlü hayata geçirilememiştir.

Yukarıda da vurgulandığı gibi Atatürk de ordu mensubu olmasına karşın askerin siyasetle herhangi bir bağının olmaması gerektiğini düşünmüştür. Aslında Atatürk, bir yandan orduyu siyasal arenanın "itiş kakış"ından uzakta tutmak ve siyasetin bir aracı haline gelmesini önlemek, diğer yandan orduya olan saygının ve güvenin devam etmesini, cumhuriyetin ve rejimin bekçiliğini yapmasını ve ulusal güvenliği sağlarken de sivil otoritenin emrinde olmasını istemişti. ${ }^{36} \mathrm{Bu}$ açıdan bakıldığında milli mücadele döneminde asker ile sivil otorite ilişkisini tanımlayan kurucu modelden şu açılardan söz edilebilir: Öncelikle, silahlı kuvvetler dolayısıyla ordu hem devlet içinde özerkliğini sürdürmüş hem de kendi içinde merkezileşmiştir. Buradaki özerkleşme, aslında ordunun bir yandan devlet içinde, diğer yandan sivil iktidar karşısında özerk bir alana sahip olmasını ifade eder. Diğer bir deyişle özerk alanda ordunun kendi işleyişini kurmada sivil iradeden bağımız davranmasıdır. Her ne kadar yasalarda askeri otoritenin sivil otoritenin emrinde olduğu yazılsa da uygulamada ilişkiler çoğunlukla tersine işlediği için askeri kimlik siyasi kimliğin üzerinde egemen olmuştur. Merkezileşme hâli ise, ordu içindeki yetkilerin hiyerarşik biçimde tek elde toplandığ ve bu yetkilerin yasal olarak sorumluluktan muaf tutulduğu duruma işaret eder. ${ }^{37}$ Türkiye'de kendi içinde hem özerkleşmiş hem de merkezileşmiş bir ordunun varlığg1, hükümetlerin askeri kurumları rahat bir biçimde denetleyememesine yol açmıştır.

Devlet mekanizması içerisinde özerkliğe ve aşırı merkeziyetçi bir kurum içi örgütlenmeye sahip olan ordunun, ${ }^{38}$ gerek ayrıcalıklı konumuyla kendisini sivil denetime açmak istememesi, gerekse ekonomik bir aktör/zümre/sınıf olarak özerk alanını genişletmeye çalışmass ${ }^{39}$ bazen bünyesinde barındırdığ 1 cuntaların devlet yönetimini ele geçirmesine neden olmuştur. ${ }^{40}$ Ancak ordunun siyasete müdahale etmesinin kurumsal gerekçeleri yanında özellikle askerlik süreci içinde alınan ideolojik eğitimin de payı büyük olmuştur. Son derece katı bir eğitimden geçen askerler, her ne kadar sivil otoriteye itaat ettiklerini söyleseler de, kendileri açısından bunun bir sınırı yoktur. Aslında bu sınır, sivil otoritenin genellikle de silahlı kuvvetler tarafından bir ideoloji haline getirilen Kemalizm'in ilkelerine uyup uymadığı noktasında belirlemektedir. Ordu, Kemalizm'in yorumuyla sivil iktidara bir takım görevler yükler ve bu görevler aksatıldığında ya da yerine getirilmediğinde ordu açısından hükümetlere müdahale etmenin hem gerekçesi, hem de meşruiyeti oluşur. ${ }^{41}$

35 Oya Çitçi, “Ordu-Siyaset İlişkileri: 1920-1938”, Amme İdaresi Dergisi, 39/4 (2006), s.41.

36 Heper, Türkiye’de Devlet Geleneği, s.101.

37 Ali Bayramoğlu, “Asker ve Siyaset”, Bir Zümre, Bir Parti Türkiye’de Ordu, der., Ahmet İnsel ve Ali Bayramoğlu, İstanbul: Birikim Yayınları, 2004, s.64.

38 Hale Akay, “Türkiye’de Asker-Sivil İlişkileri: 2000-2011 Dönemine İlişkin Bir Değerlendirme”, https://www. hyd.org.tr/attachments/article/123/asker_sivil_hale_akay.pdf.

39 Hamit Bozarslan, Türkiye’nin Modern Tarihi, çev., Heval Bucak, İstanbul: Avesta Yayınları, 2008, s.129.

40 Mehmet Kabasakal, Türkiye’de Siyasal Yaşam, Dün, Bugün, Yarın, der., Mehmet Kabasakal, İstanbul: İstanbul Bilgi Üniversitesi Yayınları, 2016, s.133.

41 Serdar Şen, Cumhuriyet Kültürünün Oluşum Sürecinde Bir İdeolojik Aygıt Olarak Silahlı Kuvvetler ve Modernizm, İstanbul: Noktakitap, 2005, s.116. 
Dolayısıyla askerlik boyunca verilen ideolojik eğitimin hem askerin dünya görüşünü ve yaşam biçimini, hem de sivil otoriteyle olan ilişkisini belirlediği söylenebilir. Burada Kemalizm’in asker-bürokrat zümre tarafından hegemonik konumlarını meşrulaştırmak için ideolojik bir araç olarak kullanıldığını söylemeye gerek yok. ${ }^{42}$ Zira Kemalizm cumhuriyet dönemi boyunca hem modernleşmenin ${ }^{43}$ hem de rejimin güvencesi olarak görülmüştür. Ordu, Kemalizm’in bu işlevi yanında milliyetçi ideolojinin yeniden üretiminin ağırlıklı bir aktörü olarak da öne çıkmıştır. Bu işlev Cumhuriyet tarihi boyunca değişmiş, ancak azalmamış, aksine artmıştır. Milli Güvenlik Kurulu'nda yer alan askerler, günlük siyasetin belirleyicisi olarak öne çıkmaya, Türk milliyetçiliği ideolojisini hegemonize etmeye ve bununla beraber milliyetçiliğin hegemonik bir ideoloji olmasını temin etmeye çalışmıştır. ${ }^{44}$ Dolayısıyla Türkiye'de askeri darbelerin sıklıkla yaşanmasının en önemli nedeninin, ordunun Kemalizm’e yüklediği ideolojik anlam ve Kemalizm’i araçsallaştırması olduğu söylenebilir.

\section{Türkiye’de Askeri Darbelerin İdeolojik Kökenleri}

Osmanlının merkeziyetçi devlet geleneğini olduğu gibi devralan Cumhuriyet rejimi, asker-sivil ilişkileri açısından sürekli sorunlar yaşamıştır. Ordu, sivil irade üzerindeki hegemonik konumunu ve kurumsal ayrıcalıklarını kaybetmemek, sivil otorite de askeri vesayeti ortadan kaldırmak suretiyle demokrasiyi güçlendirmek ve milli iradeyi egemen kılmak için sürekli mücadele vermiştir. Geç Osmanlı döneminden başlayıp günümüze kadar devam bu mücadelede askerler genellikle darbe yaparak yönetime el koymuşlardır. Asker ve sivil yönetim arasındaki mücadelenin temelinde her ne kadar sınıfsal bir çatışma olduğu düşünülse de, aslında bu mücadelenin en önemli yanının ideolojik nedenler olduğu söylenebilir. Bu ideolojik nedenleri şu başlık altında toplamak mümkündür.

1. Türkiye'de askeri darbelerin ideolojik nedenlerinden birisi, Türk Silahlı Kuvvetleri mensuplarının kendilerini devletin asli unsuru olarak görmeleridir. Bu ideolojik bakış açısı, yani bir kurum olarak ordunun kendisini devletle özdeşleştirmesi, başta siyaset olmak üzere diğer kurumlara güvenmemesi anlamına gelir ki, askerler aldıkları eğitim nedeniyle her ne kadar sivil otoritenin emrinde olduklarını söyleseler de pratikte buna pek uymamışlardır. Burada devleti kuran bir güç olarak ordunun aynı zamanda devletin asli sahibi olduğunu düşünmesi ve kendisini romantik bir sahiplenme duygusuna kaptırması, kimi zaman darbe girişiminde bulunmasının ideolojik nedenini oluşturmuştur.

2. Türk Silahlı Kuvvetleri mensupları, gerek askeri okullarda edindikleri formasyon, gerekse mesleki yaşamlarında aldıkları eğitim nedeniyle olsa gerektir, özellikle ülke sorunları konusunda her zaman tavrını, rengini ortaya koymuşlardır. Ordu mensuplarının başta askeri okullarda yetiştirilme tarzları ve vatan uğruna savaşma-

42 Ömer Laçiner, “Türk Militarizmi-I”, Bir Zümre, Bir Parti Türkiye’de Ordu, der., Ahmet İnsel ve Ali Bayramoğlu, İstanbul: Birikim Yayınları, 2004, s.21.

43 Tanıl Bora, Türk Sağının Üç Hâli: Milliyetçilik, Muhafazakârlık, İslamcılık, İstanbul: Birikim Yayınları, 2014, s.71.

44 Ayşegül Altınay ve Tanıl Bora, “Ordu, Militarizm ve Milliyetçilik”, Modern Türkiye’de Siyasi Düşünce: Milliyetçilik, ed., Tanıl Bora ve Murat Gültekingil, İstanbul: İletişim Yayınları, 2003, s.159. 
ları olmak üzere; modernist, pozitivist, milliyetçi ve devletçi bir pedagojiden geçmeleri, ${ }^{45}$ onların sadece halktan farklı düşünmelerini değil, aynı zamanda ülkenin idaresinden ekonomisine, eğitiminden savunmasına kadar tüm süreçlerde siyaseti yönlendirmesine de neden olmuştur.

3. Türkiye’de ordu, gerek Osmanlı'dan gelen köklü geleneği ve sivil irade üzerindeki hegemonyasıyla, gerekse milliyetçi söylem tarafından göklere çıkarılan ve zorunlu askerlik uygulamasının kendisine sağladığı destekle meşruiyetini güçlendirdiği için ${ }^{46}$ sivil otorite karşısında yönetilen bir güç olmayı pek istememiştir. Zira aşkın devlet geleneği tarafından kuşatılan ordu, zamanla hem hegemonik konumunu güçlendirmiş hem de sivil irade üzerinde etkili olmaya başlamıştır. Ayrıca ordunun tarihsel geçmişinin köklü, toplumsal desteğinin güçlü olması, kendisini hem eleştirilemez ve sorgulanamaz bir pozisyonda görmesine, hem de değişimin ve modernleşmenin öncüsü olarak hareket etmesine yol açmıştır.

4. Askeri müdahalelerin meydana gelmesinde rol oynayan diğer ideolojik bir neden de ordunun, devletin ve rejimin sürekli bir tehdit durumuyla karşı kaşıya olduğunu iddia etmesidir. Askerler, 1960’tan beri yapmış oldukları her darbede, bir yandan ülkenin sivil otorite eliyle siyasal istikrarsızlığa sürüklendiğini ve toplumsal çatı̧smaların önüne geçilemediğini gerekçe göstermiş, diğer yandan Kemalizm’i bir hegemeonik söylemsel araç olarak kullanarak kendisini savunmaya çalışmıştır. ${ }^{47}$ Nitekim her darbe sonrasında ordu, sivil iradenin Kemalizm'den saptığı ve devrim kanunlarına ihanet ettiği gerekçesini öne sürerek sivilleri suçlamıştır. Ayrıca uzun yıllar İç Hizmetler Kanunu'nun ilgili maddesinin arkasına sı̆̆ınarak Türkiye Cumhuriyeti’ni korumak ve kollamak amacıyla darbe yaptığını iddia etmiştir

5. Türkiye'de gerçekleşen darbelerin gerekçelerine baktığımızda ordunun her zaman rejimin tehlikede olduğu savını öne sürdüğünü görürüz. Ordunun bu türden bir savunma yapmasının temel nedeni, Türk Silahlı Kuvvetlerinin dönüştürücü bir kamu felsefesinin (Kemalizm'in) kurucu, taşıyıcı ve yayıcı bir ajanı olarak, laiklik, modernlik ve çağdaş medeniyete ayak uydurma şeklinde algıladığı rejimin temel payandalarının muhafızlığı rolünü tarihsel olarak özümsemiş ve içselleştirmiş olmasından kaynaklandığını ve bu payandaların tehlikeye girdiğini gördüğü anda da, biçimi ne olursa olsun müdahale etmekten çekinmediğini görüyoruz. ${ }^{48}$

6. Ordunun sürekli güvenlik ve tehdit riskini öne çıkarması, bir yandan siyaset üzerinde daha fazla etkin olmasını, diğer yandan ülkenin iç ve dış politikalarında daha aktif olmasını sağlamıştır. Bu durumun en bariz örneği, 1980’lerden beri Türkiye’nin en önemli sorunu haline gelen ve bir türlü çözüme kavuşturulamadığı için de gittikçe kronikleşen Kürt meselesinde ordunun takındığg tutumdur. Söz konusu sorun karşısında politika geliştirme önceliğini elinde bulunduran ordu, “teröre ve bölücü-

45 Jacop M Landau, Atatürk ve Türkiye’nin Modernleşmesi, çev., Meral Alakuş, İstanbul: Sarmal Yayınları, 1999, s.35.

46 Ünsaldı, Türkiye'de Asker ve Siyaset, s.15.

47 Çiler Dursun, “Türkiye’de Darbelerin Simgesel Ekonomisi”, Doğu Batı Dergisi, 21 (2002), s.3.

48 Ümit Cizre, "Egemen İdeoloji ve Türk Silahlı Kuvvetleri: Kavramsal ve İlișkisel Bir Analiz”, Bir Zümre, Bir Parti

Türkiye’de Ordu, der., Ahmet İnsel ve Ali Bayramoğlu, İstanbul: Birikim Yayınları, 2004, s.140-153. 
lüğe karşı mücadele eden "milli güç" imajıyla toplumsal meşruiyetini tazeleyip güçlendirme olanağı bulmuştur. ${ }^{49}$ Bunun yanında Atatürk devrimlerini, laiklik ve Türk milliyetçiliğini iç ve dış düşmanlardan koruma misyonunu edinmesi, ordunun siyasetteki ayrıcalıklı ve hegemonik konumunu pekiştiren bir diğer faktör olmuştur. ${ }^{50}$ Kısaca darbelerin en önemli ideolojik nedeninin, ordunun sürekli bir düşman fobisi içinde hareket ederek iç ve dış düşmanlarla örülü bir coğrafyayı korumaya çalıştığını iddia etmesidir denilebilir.

7. Türk Silahlı Kuvvetlerinin halkın daveti ve talebi üzerine yönetime el koyduğu iddiası, askeri darbelerin ideolojik nedenlerinden ve gerekçelerinden birini oluşturmuştur. Ordu, her defasında aslında darbe yapmak istemediğini buna mecbur bırakıldığını, aksi durumda devletin ve rejimin tehlikeye girebileceğini iddia etmiştir. Nitekim darbe sonrasında komutanlar basına verdikleri demeçte, ülkede yaşanan krizin daha fazla derinleşmemesi ve olağanüstü koşulların ortadan kaldırılması için ordunun yönetime el koyduğunu iddiasında bulunmuşlardır. Bu iddianın en somut örneği, Kenan Evren’in 2 Temmuz 1987'de basına verdiği beyanattır. Evren "Silahlı Kuvvetler akıllarına estiği için darbe yapmazlar. Milletin davet etmesi üzerine yaparlar. Millet 12 Eylül'ü istedi, (orduyu harekete geçmeye) zorladı. Darbe, büyük bir zorlamayla gerçekleştirildi. Bu olmasaydı 12 Eylüle kadar beklemezdik" ${ }^{51}$ diyerek topluma darbenin gerekçesini izah etmeye çalışmıştır.

8. Türkiye'de darbelerin sıkça yaşanmasının bir diğer ideolojik nedeni de, toplumda bazı kesimlerin ülke sorunlarının çözümünde sivil iradeye ve demokratik kurumlara güven duymadıkları için olağanüstü özellikleri olduğuna inandıkları TSK’nin nihai anlamda sorunları en iyi çözebilecek kurumun olduğunu düşünmeleri ve en ufak bir krizde askerleri yönetime el koyması için davet etmeleridir. Nitekim her dönemde darbeleri alkışlayan ve hükümete karşı oldukları için askeri vesayeti isteyen kesimler olmuştur. ${ }^{52}$ Zaten ordu bugüne kadar gerçekleştirdiği darbelerde vesayet gücünü söz konusu kesimlerin ki, -bunların başında yargı, bürokrasi, medya, üniversite, bazı sivil toplum kuruluşları gelmiştir- kendilerine verdiği destekten almıştır. ${ }^{53} \mathrm{Ordu}$, siyaset üzerinde vesayet kurulmasını isteyen kesimlerin taleplerini darbe yaparak geri çevirmemiştir.

9. Darbelerin ideolojik nedenleri arasında bulunan "demokrasinin yeniden inşa edilmesi ve milli iradenin egemen kılınması" iddiası, darbe sonrasinda ordu tarafindan sıkça dile getirilmiştir. Genellikle siyaset yazınında askeri müdahalelerin demokrasiyi ortadan kaldırmak için değil, demokrasiyi daha fazla işler hale getirmek için

49 Ahmet İnsel, Düzen ve Kalkınma Kıskacında Türkiye: Kalkınma Sürecinde Devletin Rolü, çev., Ayşegül Sönmezsoy, İstanbul: Ayrıntı Yayınları, 1996, s.339.

50 Begüm Burak, “Osmanlıdan Günümüze Ordu-Siyaset İlişkileri”, History Studies, 3/1 (2011), s.45-67.

51 Feroz Ahmad, Modern Türkiye’nin Oluşumu, çev., Yavuz Alogan, İstanbul: Sarmal Yayınları, 1995, s.298.

52 Abdulvahap Akınc1, “Türk Siyasal Hayatında 1980 Sonrası Darbeler ve E-Muhtıra”, Trakya Üniversitesi Sosyal Bilimler Dergisi, 15/2 (2013), s.56.

53 Ahmet T. Kuru, “Türkiye’de Askeri Vesayetin Yükseliş ve Düşüşü: İslamcıllk Kürtçülük ve Komünizm Korkuları”, Türkiye’de Demokrasi, İslam ve Laiklik, der., Ahmet T. Kuru ve Alfred Stepan, İstanbul: İstanbul Bilgi Üniversitesi Yayınları, 2013, s.58. 
yapıldığ $1,{ }^{54}$ aynı şekilde ordunun iktidarın bekçisi olmadığını ve olamayacağı, esas amacın bir an önce ülkede asayişin sağlanarak sükûnet içinde iktidara gelecek bir hükümetin Türk Silahlı Kuvvetlerinin teamüllerine ve hassasiyetlerine (Atatürk ilkeleri, laiklik, Türk milliyetçiliği vb) riayet etmek koşuluyla ülkeyi yönetmesi olduğu tezi savunulur.

10. Aslında Türk Silahlı Kuvvetlerinin darbe sonrasında ve düzeni tesis ettikten sonra yeniden demokrasiye geçmek ve yönetimi sivil iktidarlara birakmak istemesinin temel nedeni, ordunun toplumda oluşan prestij kaybını azaltmaya çalışmasıdır. Askeri müdahale dönemlerinin kısa süreli olmasının nedeni de budur. Zira ordunun uzun süre yönetimde kalması halinde bir yandan uluslararası arenada insan hakları ihlallerinin gündeme gelmesi mümkün olabilecek, diğer yandan ordunun siyasal, ekonomik ve askeri başarısızlıklarının müsebbibi olarak görülme riski doğabilecektir. ${ }^{55} \mathrm{Bu}$ riskleri göze almak istemeyen ordu, müdahale sonrasında ortalık yatışır yatışmaz tekrar yönetimi sivillere bırakarak hem kurumsal kimliğinin hem de toplumdaki saygınlığının zedelenmesini önlemiş olmaktadır.

\section{Sonuç}

Türkiye'de genellikle ordu-siyaset yazınında üzerinde ittifak edilen temel husus, askeri bir geleneğe sahip olan Osmanlı'nın duraklama dönemine kadar sivil ve asker ilişkilerinde bir denge yaşadığı, ancak imparatorluğun gerilemesiyle beraber ordunun hem siyaset üzerinde hegemonya kurduğu, hem de askeri alanda yapılan reformlara şiddetle karşı çıktığı yönündedir. Savaşlarda yaşanan yenilginin ve büyük toprak kayıplarının müsebbibi olarak görülen ordunun modernize edilmeye çalışılması, sınıfsal çıkarını imparatorluğun menfaatleri üzerinde gören askerlerin sivil iradeye müdahale etmesine neden olmuştur.

1908'de II. Meşrutiyetin ilanına yol açan Jön Türk darbesi zaman içinde adeta bir gelenek halini alarak cumhuriyet dönemine de sirayet etmiştir. Silahlı kuvvetlerin gerek yasalarda gerekse sivil hükümetler karşısında kendisini mutlak bir güç olarak tanımlaması, devletin asli unsuru ve koruyucusu olduğunu iddia etmesi ama daha da önemlisi siyasetin kurucu bir öznesi gibi hareket ederek hem modernleşmenin öncülügünü hem de Kemalist rejimin koruyuculuğunu üstlenmesi, sadece sivil otorite nezdinde değil aynı zamanda toplum karşısında da hegemonik konumunun güçlenmesine neden olmuştur. Ordu, geleneksel ve kurumsal gücünü sivil irade üzerinde bir baskı unsuru olarak kullanmıştır.

Tarihsel açıdan Türkiye’nin en eski kurumu olan ordu, kendisini devrimlerin takipçisi, devletin ve rejimin koruyucusu olarak gördüğü için çoğu kez sivil otoritelerle görüş ayrılıkları yaşamış, toplumsal, siyasal ve ekonomik yaşamı ilgilendiren konularda demeçler vermiş, siyasetteki ağırlığı yanında savunma ve iktisadi faaliyetlerde de aktif rol almıştır. Bir kurum olarak ordunun, siyasete müdahalesinin istisna olmaktan çıkarak adeta bir kural haline gelmesini, sadece silahlı gücü elinde bulun-

54 Heper, Türkiye’de Devlet Geleneği, s.251-252.

55 Cizre, “Egemen İdeoloji ve Türk Silahlı Kuvvetleri: Kavramsal ve İlişkisel Bir Analiz”, s.369. 
durmasıyla açıklanamaz. Hiç şüphesiz ki, meydana gelen darbelerin özel ve genel sebepleri olmakla birlikte en önemlisi ideolojik olanıdır.

Askeri darbelerin en önemli ideolojik nedeni, ordunun anayasa ve yasalarda kendisini tanımlama ve görme biçimidir. Zira ordunun, dokunulmayan, denetlenmeyen ve dolayısıyla özerk bir yapı olarak kendisini siyaset üstü ve hikmetinden sual edilmez bir konumda görmesi, Türk siyasal hayatındaki önceliğinin ve bir kurum olarak da hegemonik gücünün pekişmesine neden olmuştur. Ordunun sürekli tehdit alg1s1na dayalı politik bir duruşu olmuştur. Bu tehdit algısının hedefleri dönemsel olarak değişse de, ordunun ulusal güvenlik adı altında gücünü muhafaza etmek, kurumsal kimliğini ve kazanımlarını sürdürmek için özel bir çaba harcadığı da bir gerçektir. $\mathrm{Bu}$ çabaların neticesinde ordu, dinamik bir güç olarak hem askeri açıdan güçlenmiş hem de sivil iktidarlar üzerindeki vesayetini sürdürmüştür.

Türkiye'de ordu, bugüne kadar birçok kez darbe yapmış, birçok kez de darbe girişiminde bulunmuştur. Gerçekleştirilen her darbe sonrasında sivillere yaptırılan anayasalarla ordunun hegemonik üstünlüğü devam etmiştir. Son elli yılda silahlı kuvvetlerin sürekli siyasete müdahale ederek yönetime el koyması, bir yandan Türk demokrasisinin büyük bir darbe yemesine, diğer yandan muhalefet ve sivil toplumun gelişememesine neden olmuştur. Türkiye'de demokratik, çoğulcu ve şeffaf bir sivil yönetimin oluşmamasının en önemli nedeni, ordunun kendisini devletle özdeşleştiren bir anlayışa sahip olması yanında toplumun da devleti aşkın bir konumda görmeye devam etmesidir.

Ancak son yıllarda Avrupa Birliği ile yapılan müzakereler ve bu müzakerelerde Kopenhag Kriterleri çerçevesinde yasal düzenlemelerin yapılması, demokrasi ve sivil siyaset adına önemli kazanımlar sağlamıştır. Bu anlamda yapılan reformlarla, askeri sistem revize edilmiş, sivil hükümetler karşısındaki hegemonik yapı kırılmış, ordunun iç güvenliği sağlamadaki kurumsal rolü azaltılmış, hukuk sistemi içindeki yetkileri daraltılmış, başta savunma harcamaları olmak üzere mali konularda hesap verebilirliği sağlanmış ve bütçe konusundaki dokunulmazlığı kaldırılmıştır. Uyum paketleri çerçevesinde yapılan değişiklikler, Türkiye'de askeri vesayetin azalmasını sağladığ 1 gibi, sivil otoritenin egemenliğini ve demokratik teamüllerin kurumsallaşmasını da güçlendirmiştir.

\section{Kaynakça}

Afyoncu, Erhan, Ahmet Önal ve Uğur Demir. Osmanl İmparatorluğu’nda Askeri İsyanlar ve Darbeler. İstanbul: Yeditepe Yayınevi, 2016.

Ahmad, Feroz. Bir Kimlik Peşinde Türkiye. Çev. Sedat C. Karadeli. İstanbul: İstanbul Bilgi Üniversitesi Yayınları, 2006.

Ahmad, Feroz. Modern Türkiye’nin Oluşumu. Çev. Yavuz Alogan. İstanbul: Sarmal Yayınları, 1995.

Akay, Hale. “Türkiye’de Asker-Sivil İlişkileri: 2000-2011 Dönemine İlişkin Bir Değerlendirme” https://www.hyd.org.tr/attachments/article/123/asker_sivil_ hale_akay.pdf. (Erişim 29.01.2017). 
Akınc1, Abdulvahap. “Türk Siyasal Hayatında 1980 Sonrası Darbeler ve e-Muhtıra”. Trakya Üniversitesi Sosyal Bilimler Dergisi. 15/2 (2013): 39-58.

Akşit, Sina. 31 Mart Olayı. Ankara: İmge Kitabevi, 2015.

Aktar, Cengiz. Türkiye’nin Batılılaştırılması. Çev. Temel Keşoğlu. İstanbul: Ayrıntı Yayınları, 1993.

Akyaz, Doğan. Askeri Müdahalelerin Orduya Etkisi. İstanbul: İletişim Yayınları, 2009. Altınay, Ayşegül ve Tanıl Bora. “Ordu, Militarizm ve Milliyetçilik”. Modern Türkiye’de Siyasi Düşünce: Milliyetçilik. Ed. Tanıl Bora ve Murat Gültekingil. İstanbul: İletişim Yayınları, 2003.

Başkaya, Fikret. Yediyüz, Ankara: Ütopya Yayınları, 1999.

Bayramoğlu, Ali. “Asker ve Siyaset”. Bir Zümre, Bir Parti Türkiye'de Ordu. Der. Ahmet İnsel ve Ali Bayramoğlu. İstanbul: Birikim Yayınları, 2004.

Berkes, Niyazi. Türkiye’de Çağdaşlaşma. İstanbul: Yapı Kredi Yayınları, 2005.

Bora, Tanıl. Türk Sağının Üç Hâli: Milliyetçilik, Muhafazakârlık, İslamcılık. İstanbul: Birikim Yayınları, 2014.

Bozarslan, Hamit. Türkiye’nin Modern Tarihi. Çev. Heval Bucak. İstanbul: Avesta Yayınları, 2008.

Burak, Begüm. "Osmanlıdan Günümüze Ordu-Siyaset İlişkileri”. History Studies. 3/1 (2011): 45-67.

Cengiz, Bengi. “İkinci Dünya Savaşı’ndan Sonra Dünyadaki Darbeler ve Darbe Girişimleri”. Son güncelleme 07 Ağustos, 2018. http://www.dogrulukpayi. com/bulten/ikinci-dunya-savasi-ndan-sonra-dunyadaki-darbeler-ve-darbegirisimleri.

Cizre, Ümit. "Egemen İdeoloji ve Türk Silahlı Kuvvetleri: Kavramsal ve İlişkisel Bir Analiz”. Bir Zümre, Bir Parti Türkiye’de Ordu, Der. Ahmet İnsel ve Ali Bayramoğlu. İstanbul: Birikim Yayınları, 2004.

Çetin, Halis. Modernleşme ve Türkiye’de Modernleştirme Krizleri. Ankara: Siyasal Kitabevi, 2003.

Çitçi, Oya. “Ordu-Siyaset İlişkileri: 1920-1938”. Amme İdaresi Dergisi. $39 / 4$ (2006): 17-44.

Dursun, Çiler. “Türkiyede Darbelerin Simgesel Ekonomisi”. Doğu Batı Dergisi. 21 (2002): 137-138.

Duverger, Maurice. Diktatörlük Üstüne. Çev. Bülent Tanör. İstanbul: Dönem Yayınlar1, 1965.

Duverger, Maurice. Politikaya Giriş. Çev. S. Tiryakioğlu. İstanbul: Varlık Yayınları, 1964.

Fukuyama, Francis. Political Order and Political Decay. New York: Farrar, Straus and Giroux, 2014.

Haberler.com. "Dünyada 1950'den Beri 475 Askeri Darbe Girişimi Oldu”. Son güncelleme 15 Ağustos, 2018. https://www.haberler.com/dunyada-1950-denberi-475-askeri-darbe-girisimi-10427351-haberi /. 
Hale, William. Türkiye’de Ordu ve Siyaset. Çev. Ahmet. Fethi. İstanbul: Hil Yayınları, 1996.

Heper, Metin. Türkiye’de Devlet Geleneği. Çev. Nalan Soyarık. Ankara: Doğu Batı, 2006.

Heywood, Andrew. Politics. New York: Palgarave Macmillan, 2007.

Huntington, Samuel P. "Political Development and Political Decay". World Politics. 17/3 (1965): 386-430.

Huntington, Samuel P. ve Jorge Dominguez. I. Siyasal Gelişme. Çev. Ergun Özbudun. Ankara: Ankara Siyasal İlimler Derneği Yayınları, 1975.

İnsel, Ahmet. Düzen ve Kalkınma Kıskacında Türkiye: Kalkınma Sürecinde Devletin Rolü. Çev. Ayşegül Sönmezsoy. İstanbul: Ayrıntı Yayınları, 1996.

Kabasakal, Mehmet. Türkiye’de Siyasal Yaşam, Dün, Bugün, Yarın. Der. Mehmet Kabasakal. İstanbul: İstanbul Bilgi Üniversitesi Yayınları, 2016.

Karatepe, Şükrü. Darbeler, Anayasalar ve Modernleşme. İstanbul: İz Yayıncılık, 1999.

Karpat, H. Kemal. Osmanlıdan Günümüze Asker ve Siyaset. İstanbul: Timaş Yayınları, 2010.

Keyder, Çağlar. Türkiye’de Devlet ve Sınıflar. İstanbul: İletişim Yayınları, 2001.

Kissinger, Henry. World Order. New York: Penguin Books, 2014.

Kuru, Ahmet T. “Türkiye’de Askeri Vesayetin Yükseliş ve Düşüşü: İslamcilık Kürtçülük ve Komünizm Korkuları”. Türkiye’de Demokrasi, Islam ve Laiklik. Der. Ahmet T. Kuru ve Alfred Stepan. İstanbul: İstanbul Bilgi Üniversitesi Yayınları, 2013.

Laçiner, Ömer. “Türk Militarizmi-I”. Bir Zümre, Bir Parti Türkiye’de Ordu. Der. Ahmet İnsel ve Ali Bayramoğlu, İstanbul: Birikim Yayınları, 2004.

Landau, Jacop M. Atatürk ve Türkiye’nin Modernleşmesi, çev. M. Alakuş, İstanbul: Sarmal Yayınları, 1999.

Maraşlı, Erol. Türkiye’de Askeri Darbe Teşebbüsleri. İstanbul: Bilgeoğuz Yayınları, 2015.

Mardin, Şerif. Jön Türklerin Siyasi Fikirleri 1895-1908. İstanbul: İletişim Yayınları, 2017.

Mardin, Şerif. Türkiye’de Toplum ve Siyaset. Der. Mümtaz’er Türköne ve Tuncay Önder. İstanbul: İletişim Yayınları, 1997.

Özbudun, Ergun. Otoriter Rejimler, Seçimsel Demokrasiler ve Türkiye. İstanbul: İstanbul Bilgi Üniversitesi Yayınları, 2011.

Öztürk, Metin. Ordu ve Politika. Ankara: Gündoğan Yayınları, 1993.

Sencer, Muzaffer. Osmanlı Toplum Yapısı. İstanbul: Sarmal Yayınları, 1999.

Steinhaus, Kurt. Atatürk Devrimi Sosyolojisi. Çev. Mehmet Akkaş. İstanbul: Sarmal Yayınlar1, 1995.

Şen, Serdar. Cumhuriyet Kültürünün Oluşum Sürecinde Bir İdeolojik Aygit Olarak Silahlı Kuvvetler ve Modernizm. İstanbul: Noktakitap, 2005.

Ünsaldı, Levent. Türkiye'de Asker ve Siyaset. İstanbul: Kitap Yayınları, 2008. 
Yeniçeri, Özcan. Genç Osman'dan Menderese Darbe ve Demokrasi. Ankara: Kripto Yayınlar1, 2015.

Zürcher, Erik Jan. Modernleșen Türkiye’nin Tarihi. Çev. Yasemin S. Gönen. İstanbul: İletişim Yayınları, 2004. 


\title{
Relation between Army and Politics in Turkey and Ideological Origins of Military Coups
}

\author{
MEHMET ZEKI DUMAN
}

\begin{abstract}
In view of the historical, social and ideological relations of army-politics and origins of these relations in Turkey, in addition to its determinant potency army identified itself with the state and positioned itself over the society politically and ideologically pioneered modernization, westernization and by Kemalism. The fact that Turkey is an army-nation state and its constitutional elements are usually made of military persona created an army which should be under the order of civil government to have a supra-political position by becoming a hegemonic power on the one hand and prevented the formation of a democratic, pluralistic and civilian society on the other hand. The way the army positions itself and defines itself at the constitutional level is one of the most important reasons for the frequent occurrence of clashes in Turkey and the inability of civilians to be powerful even if they are in power. This study aimed at disclosing the ideological origins of these causes and tries to answer the question "Why do military coups take place in Turkey?".
\end{abstract}

Keywords: Military coups, Army-politics relation, State-nation culture, Democratization, State of law. 